\title{
A Study by Polarization Techniques of the Corrosion Rates of Aluminum and Steel Underground for Six- teen Months
}

\author{
W. J. Schwerdtfeger
}

(July 6, 1961)

\begin{abstract}
One aluminum and one steel specimen were exposed underground for 16 months in order to make a running survey of their corrosion rates as influenced by weather and time.

Cathodic and anodic data were obtained periodically as a basis for calculating rates of corrosion. Automatic polarizing and recording equipment, housed indoors, was used for making the measurements. The method is adaptable for field use in making corrosion rate or soil corrosivity studies where commercial power sources are not available.
\end{abstract}

\section{Introduction}

The present investigation was carried out to evaluate polarization techniques for measuring rates of corrosion of aluminum and steel underground. An exposure period of at least 1 vear was decided upon in order to study the effects of time and climatic changes on the corrosion rates of these materials in one environment. For convenience, both materials were placed underground outside of the laboratory which housed the measuring apparatus.

The theory upon which the measurements were based has been applied to the measurement of local action corrosion currents on steel exposed to aqueous environments in the laboratory [1]. ${ }^{1}$ Briefly stated, the method consists of noting the value of cathodic and anodic current applied in increasing amounts to a corroding specimen which coincides with a change-in-slope (break) in the respective polarization curve and which is indicative of the current necessary to stop local-action corrosion.

A logarithmic relationship between the value of current at the break in the controlling polarization curve and the rate of polarization (based on the curve) was observed to be reasonably applicable to both the steel and the aluminum. A similar relationship was described previously [2] together with related work of other investigators [3].

The technique described here could be put to practical use in the field for measuring corrosion rates (based on weight loss), screening metals and alloys for long-time exposure in aqueous environments, or for measuring soil corrosivity.

\section{Experimental Procedure}

\subsection{Preparation and Exposure of Specimens}

Two specimens were used, one of low carbon steel and one of high purity aluminum. Each specimen was in the form of a tube (about 1.87 in. o.d. by 12 in. long) with rubber caps sealed on the ends, leaving about $0.4 \mathrm{ft}^{2}$ of outer surface for exposure to the soil.

\footnotetext{
Figures in brackets indicate the literature references at the end of this paper.
}

Before capping, the ends of the specimens were rounded with a file and smoothed with fine abrasive cloth. The outer and inner surfaces of the steel tube were cleaned with a motor-driven wire brush to remove any trace of scale or superficial rust. The surfaces of the aluminum tube were polished with fine abrasive cloth, and scrubbed under hot water. Each specimen was then weighed to the nearest milligram. An insulated stranded-copper wire was then soldered to an inside edge of each tube and the soldered joint coated with paint. Next, the inside surfaces of the tubes were coated with a film of rust-preventive oil and the rubber caps pressed on and sealed. The lead wire came through a hole bored in the center of one of the caps. The area where the wire protruded was sealed with bitumen.

The two specimens were buried underground outside of the laboratory, Washington, D.C., in soil having a resistivity of about 7500 ohm-cm. They were spaced $3 \mathrm{ft}$ apart in a vertical position in holes dug 30 in. deep with a post-hole auger. An auxiliary electrode (steel channel $1.5 \mathrm{in}$. by $4 \mathrm{in}$. by 19 in.) was similarly buried about $20 \mathrm{ft}$ away from the specimens. The rubber-covered wires from the specimens, auxiliary electrode and one for a reference electrode, led to the laboratory where polarization measurements were made.

\subsection{Electrical Measurements}

Potential and polarization measurements were made periodically (on 40 occasions) during the 16 months that the specimens were exposed. The separate potentials were measured with a 200,000 $\mathrm{ohm} / \mathrm{v}$ voltmeter and the polarization data were obtained with a two-pen (current and potential) strip-chart recorder. The circuit used for balancing out IR drop, automatically applying polarizing current, and recording current and potential, has been previously described [4]. A copper-copper sulfate half-cell was used for the reference electrode. When measurements were to be made, the reference electrode was placed on the surface of the earth about $3 \mathrm{ft}$ from the specimens and between them and the auxiliary electrode. The auxiliary electrode served either as an anode or a cathode. 
Apparatus for obtaining polarization data has also been built for field use by using dry batteries and controls for manually varying the polarizing current. Portable indicating-type instruments consisting of a potentiometer (galvanometer-type null indicator) and a milliammeter are used. An earthauger (1 in. diam) appropriately fitted with a crossbar for turning, is used as the auxiliary electrode. When obtaining polarization data in the field equal increments of polarizing current are applied at approximately equal time intervals (1 or 2 min intervals).

\subsection{Removal of Corrosion Products}

After 483 days of underground exposure, the aluminum and steel specimens were removed for cleaning, weight loss determinations and pit-depth measurements. The aluminum specimen was submerged in hot water and brushed with a stiff-bristle brush. After the rubber caps were taken off, the wire and solder were removed by applying heat from a soldering iron. The specimen was then placed in concentrated nitric acid for $5 \mathrm{~min}$, washed in running water, dried, and weighed. The effectiveness of the cleaning procedure was checked by repeating the nitric acid treatment and reweighing. There was no significant difference between the two weighings, indicating that the specimen was free of corrosion products.

Rust which had formed on the steel specimen was very adherent. First, the steel was cleaned cathodically in a 3 percent $\mathrm{NaCl}$ solution for $5 \mathrm{hr}$ at a current density of $1 \mathrm{amp} / \mathrm{ft}^{2}$ The specimen was then immersed for $2 \mathrm{hr}$ in a 10 percent ammonium citrate solution (at $150{ }^{\circ} \mathrm{F}$ ) made alkaline with ammonium hydroxide. Finally the steel was hand brushed (wire brush), washed, dried, and weighed.

\section{Results and Discussion}

Some of the polarization data covering the 16 months of exposure are shown for steel and aluminum, respectively, in figures 1 and 2 . The dates are given so that the data can be related to the time of year. The initial curves were obtained after the specimens were in the ground for 3 days and the final curves shown were run on the day preceding their removal. All data were taken from the recorder charts and plotted on semi-log scale. The corrosion current controls the magnitude of the polarizing currents $I p$ and $I q[1]$, indicated by the breaks in the curves (fig. 1 and 2). It will be observed in figures 1 and 2 , that the current $I q$ approaches in value the current $I p$ with the passing of time, particularly for the steel. Thus, the tendency is a change from cathodic to mixed control.

The polarizing currents, Ip and $I q$, used in calculating the values of corrosion current were obtained as shown in figures 1 and 2 . Polarization rates $(\Delta V / \Delta I)$ were calculated at the slightly larger values of current indicated by arrows on the curves. These rates seem to bear a logarithmic relation to the currents $I p$ as shown by previous work [2]. Data from the previous work on steel in a $\mathrm{NaCl}$ solution and

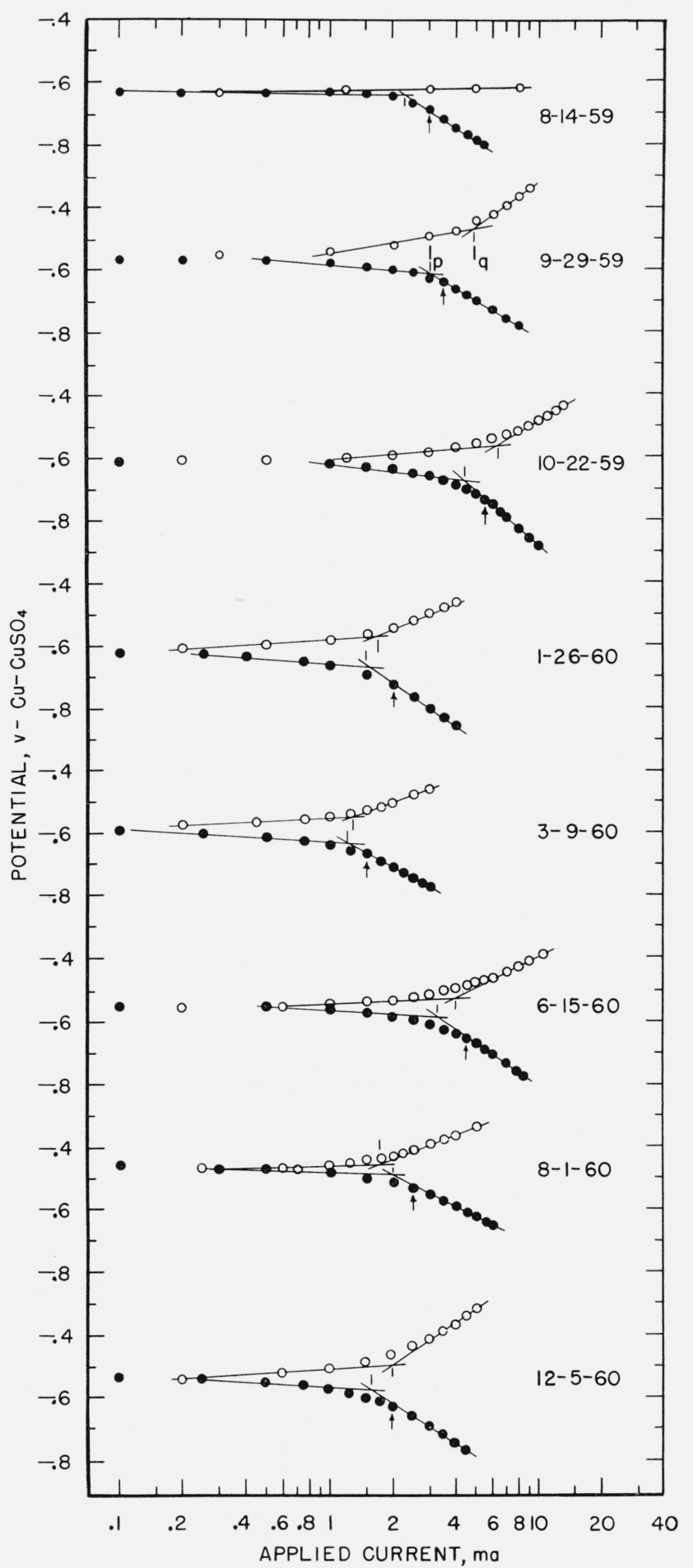

FIGURE 1. Typical polarization curves of the underground steel specimen during the 16 month exposure period. Cathodic, Anodic.

To convert applied current to current density (ma/ft²), multiply by 2.5 .

the present data are shown in figure 3 . The present data for aluminum also appear to fit reasonably well. Thus, knowing the polarization rate $(\Delta V / \Delta I)$, it is possible to estimate the current Ip from the 


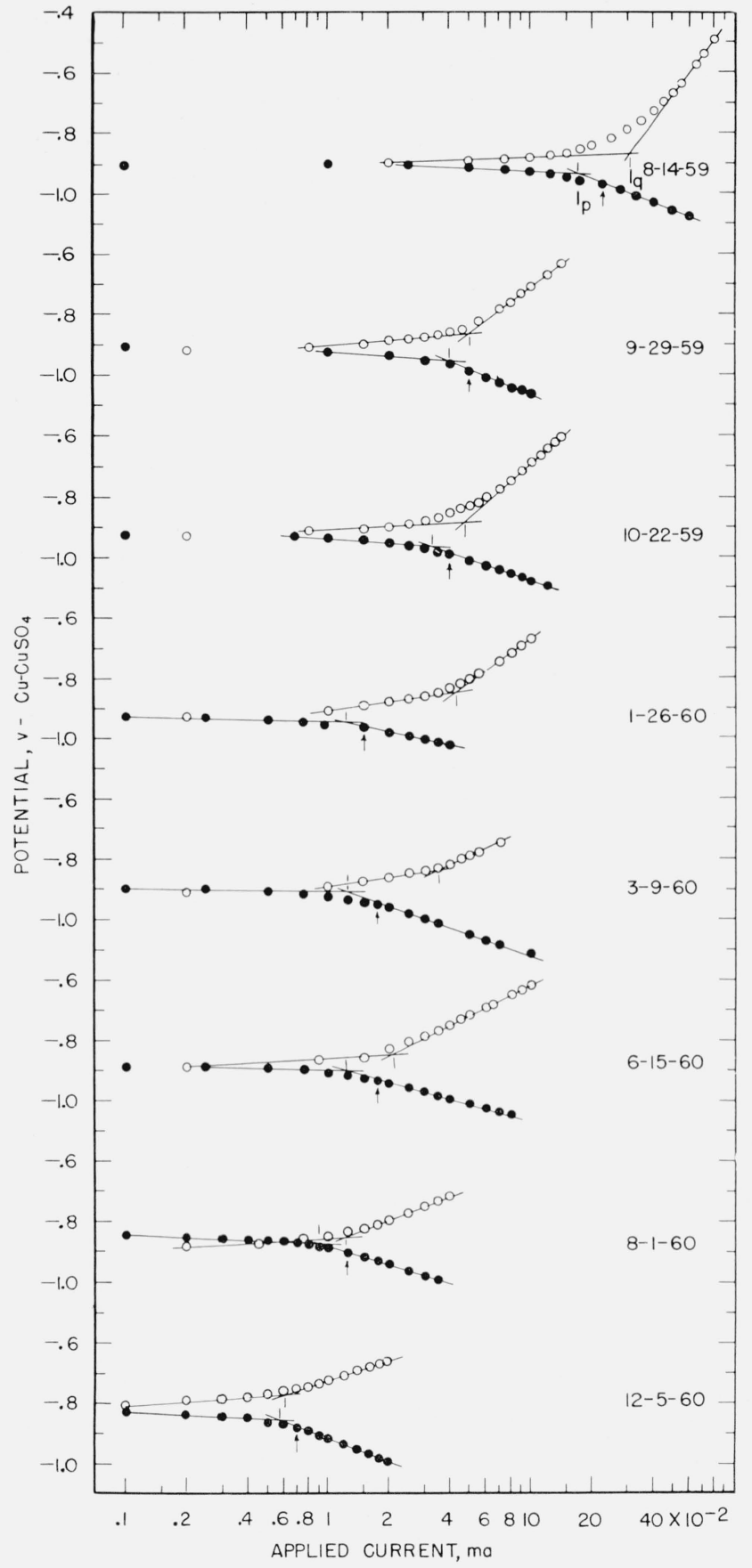

FIGURE 2. Typical polarization curves of the underground aluminum specimen during the 16 month exposure period. - Cathodic, Anodic.

To convert applied current to current density (ma/ft²), multiply by 2.5 .

curve (fig. 3). The empirical equation for data (fig. 3) may be written:

$I p=c R^{-n}$; or $\log I p=\log c-n \log R$., where $c=100$ (y-intercept), $R=\Delta V / \Delta I$ in $\mathrm{mv} / \mathrm{ma} / \mathrm{ft}^{2}$, $n=-1.1$ (slope of curve) and $I p$ is expressed in $\mathrm{ma} / \mathrm{ft}^{2}$

This relationship would be useful where the break in the curve is not readily apparent. The author is currently investigating the scope of this relation-

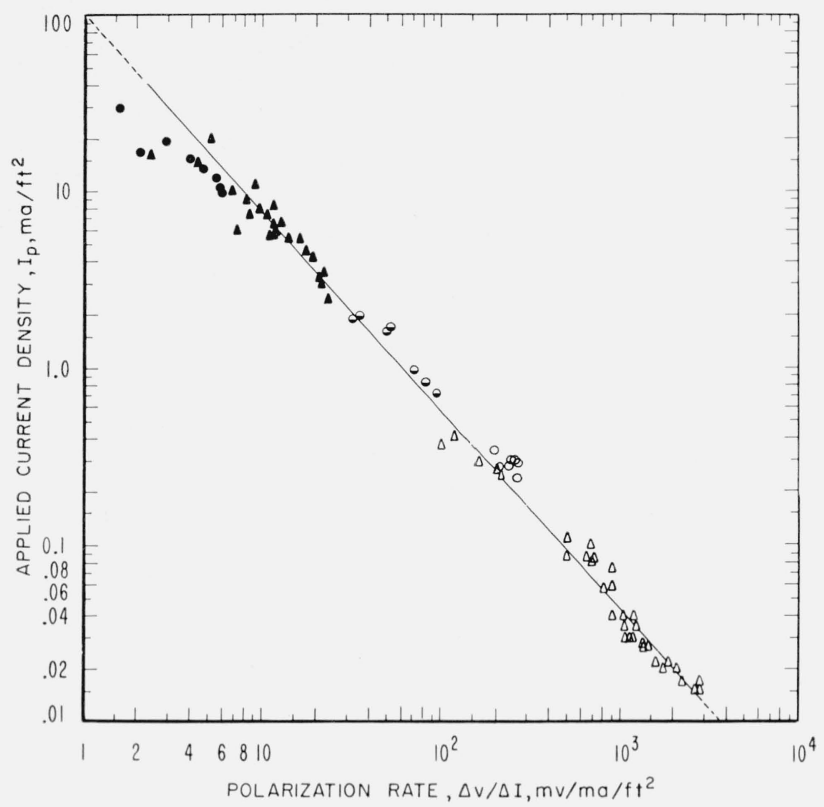

FIGURE 3. Logarithmic relationship (cathodic polarization), for steel and aluminum, between the polarizing current, Ip, and the polarization rate, $\Delta V / \Delta I$.

$\Delta$ Bare steel underground (covering 16 months exposure); $\triangle$ bare aluminum underground (covering 16 months exposure); bare steel in 3 percent sodium chloride solution (covering 14 days exposure); coated steel (carbonate coating) in 3 percent sodium chloride solution (covering 29 days exposure); $\bullet$ coated steel (carbonate, progressively damaged) in 3 percent sodium chloride solution (covering 36 days exposure).

ship with possible application to ferrous alloys such as stainless steels. When the type of control is predominantly anodic, the anodic polarization data should fit the relationship.

All data obtained for the steel and aluminum from the polarization curves (semi-log scale) used for calculating weight losses are shown respectively in tables 1 and 2. The calculated and actual weight loss for steel agree within 6 percent. On a percentage basis the same cannot be said for the aluminum but, considering the relatively small weight loss involved, the calculated weight loss is considered quite significant. Actually, the difference (about $50 \mathrm{mg}$ ) between the actual (as weighed) and calculated corrosion losses could be largely cleaning error for a soft metal such as aluminum.

For the first 3 months of exposure, polarization data were obtained more frequently than later. During this initial period, changes in the corrosion rate of both steel and aluminum appeared to be occurring frequently. Also, the corrosion rates were higher and seemed to be influenced more by changes in the weather and the passing of time. The effects of time, temperature, and rainfall on the corrosion current for steel and aluminum in this particular underground environment are shown in figure 4 . Potentials of both the steel and alu ninum are also plotted with soil resistance and climatological data. For the steel, the corrosion current $\left(i_{0}\right)$ varied considerably for the first 2 months of exposure. The rainfall early in September 1959 and again early in October lowered the soil resistance and apparently caused the two peaks (fig. 4) in the corrosion current. 
TABLE 1. Weight loss calculated from polarization data on a steel specimen exposed underground for 16 months

\begin{tabular}{|c|c|c|c|c|c|c|}
\hline \multirow{2}{*}{$\begin{array}{l}\text { Time of } \\
\text { year }\end{array}$} & \multicolumn{2}{|c|}{$\begin{array}{l}\text { Polarizing current a } \\
\text { at break in curve }\end{array}$} & \multirow{2}{*}{$\begin{array}{c}\text { Corro- } \\
\text { sion b } \\
\text { current } \\
i_{o}\end{array}$} & \multirow{2}{*}{$\begin{array}{c}\text { Exposure } \\
\text { time }\end{array}$} & \multicolumn{2}{|c|}{ Weight loss } \\
\hline & $\begin{array}{c}\text { Cathodic } \\
\quad I p\end{array}$ & $\begin{array}{l}\text { Anodic } \\
I q\end{array}$ & & & $\begin{array}{l}\text { Calculated } \\
\text { cumulative }\end{array}$ & Actual \\
\hline $\begin{array}{c}8-12-59 \\
14 \\
19 \\
25\end{array}$ & $\begin{array}{l}m a \\
2.5 \\
2.3 \\
2.4 \\
2.3\end{array}$ & $\begin{array}{c}m a \\
10.0^{\mathrm{d}} \\
9.2^{\mathrm{e}} \\
4.8^{\mathrm{d}} \\
4.6^{\mathrm{d}}\end{array}$ & $\begin{array}{l}m a \\
2.0 \\
1.8 \\
1.6 \\
1.5\end{array}$ & $\begin{array}{r}\text { Days } \\
1 \\
3 \\
8 \\
14\end{array}$ & $\begin{array}{r}m g \\
50 \\
145 \\
357 \\
582\end{array}$ & $m g$ \\
\hline $\begin{array}{c}9-4-59 \\
8 \\
18 \\
29\end{array}$ & $\begin{array}{l}6.6 \\
5.9 \\
3.5 \\
3.0\end{array}$ & $\begin{array}{l}13.2 \mathrm{~d} \\
8.4 \mathrm{e} \\
4.2 \\
5.0\end{array}$ & $\begin{array}{l}4.4 \\
3.5 \\
1.9 \\
1.9\end{array}$ & $\begin{array}{l}24 \\
28 \\
38 \\
49\end{array}$ & $\begin{array}{l}1332 \\
1712 \\
2387 \\
2909\end{array}$ & \\
\hline $\begin{array}{c}10-1-59 \\
9 \\
22\end{array}$ & $\begin{array}{l}7.9 \\
4.1 \\
4.4\end{array}$ & $\begin{array}{c}13.5^{\mathrm{e}} \\
6.7^{2} \\
6.4\end{array}$ & $\begin{array}{l}5.0 \\
2.5 \\
2.6\end{array}$ & $\begin{array}{l}51 \\
59 \\
72\end{array}$ & $\begin{array}{l}3084 \\
3824 \\
4669\end{array}$ & \\
\hline $\begin{array}{c}11-4-59 \\
13 \\
30\end{array}$ & $\begin{array}{l}2.3 \\
2.8 \\
2.7\end{array}$ & $\begin{array}{l}7.3 \\
7.7 \\
6.5\end{array}$ & $\begin{array}{l}2.3 \\
2.1 \\
1.9\end{array}$ & $\begin{array}{r}85 \\
94 \\
111\end{array}$ & $\begin{array}{l}5482 \\
5978 \\
6828\end{array}$ & \\
\hline $12-22-59$ & 2.0 & 4.9 & 1.4 & 133 & 7708 & \\
\hline$\underset{26}{1-13-60}$ & $\begin{array}{l}1.9 \\
1.4\end{array}$ & $\begin{array}{l}2.8^{\mathrm{e}} \\
1.7^{\circ}\end{array}$ & $\begin{array}{l}1.1 \\
0.77\end{array}$ & $\begin{array}{l}155 \\
168\end{array}$ & $\begin{array}{l}8423 \\
8725\end{array}$ & \\
\hline $2-19-60$ & 1.3 & $1.4 \mathrm{e}$ & 0.67 & 192 & 9157 & \\
\hline $\begin{array}{c}3-4-60 \\
9 \\
25\end{array}$ & $\begin{array}{l}1.0 \\
1.2 \\
1.7\end{array}$ & $\begin{array}{l}1.5 \\
1.3 \\
1.9\end{array}$ & $\begin{array}{l}0.60 \\
0.62 \\
0.90\end{array}$ & $\begin{array}{l}206 \\
211 \\
227\end{array}$ & $\begin{array}{l}9381 \\
9457 \\
9761\end{array}$ & \\
\hline $\begin{array}{l}4-6-60 \\
28\end{array}$ & $\begin{array}{l}2.2 \\
2.7\end{array}$ & $\begin{array}{l}2.3 \\
2.7 \mathrm{~d}\end{array}$ & $\begin{array}{l}1.1 \\
1.3\end{array}$ & $\begin{array}{l}239 \\
261\end{array}$ & $\begin{array}{l}10061 \\
10721\end{array}$ & \\
\hline$\underset{23}{5-20-60}$ & $\begin{array}{l}2.5 \\
3.0\end{array}$ & $\begin{array}{l}2.5 \\
3.0 \mathrm{~d}\end{array}$ & $\begin{array}{l}1.3 \\
1.5\end{array}$ & $\begin{array}{l}283 \\
286\end{array}$ & $\begin{array}{l}11435 \\
11540\end{array}$ & \\
\hline $\begin{array}{c}6-2-60 \\
15 \\
30\end{array}$ & $\begin{array}{l}3.5 \\
3.2 \\
2.7\end{array}$ & $\begin{array}{l}3.55^{\mathrm{d}} \\
4.0 \\
3.0\end{array}$ & $\begin{array}{l}1.8 \\
1.8 \\
1.4\end{array}$ & $\begin{array}{l}296 \\
309 \\
324\end{array}$ & $\begin{array}{l}11940 \\
12526 \\
13088\end{array}$ & \\
\hline $\begin{array}{c}7-18-60 \\
26 \\
28\end{array}$ & $\begin{array}{l}2.2 \\
2.3 \\
1.9\end{array}$ & $\begin{array}{l}2.6 \\
2.6 \\
1.8\end{array}$ & $\begin{array}{l}1.2 \\
1.2 \\
0.92\end{array}$ & $\begin{array}{l}342 \\
350 \\
352\end{array}$ & $\begin{array}{l}13674 \\
13914 \\
13969\end{array}$ & \\
\hline $\begin{array}{c}8-1-60 \\
19\end{array}$ & $\begin{array}{l}1.9 \\
3.6\end{array}$ & $\begin{array}{l}1.7 \\
3.4\end{array}$ & $\begin{array}{l}0.90 \\
1.7\end{array}$ & $\begin{array}{l}356 \\
374\end{array}$ & $\begin{array}{l}14060 \\
14645\end{array}$ & \\
\hline $\begin{array}{l}9-1-60 \\
14\end{array}$ & $\begin{array}{l}2.2 \\
3.0\end{array}$ & $\begin{array}{l}2.3 \\
3.1\end{array}$ & $\begin{array}{l}1.1 \\
1.5\end{array}$ & $\begin{array}{l}387 \\
400\end{array}$ & $\begin{array}{l}15100 \\
15522\end{array}$ & \\
\hline $\begin{array}{c}10-11-60 \\
26\end{array}$ & $\begin{array}{l}2.9 \\
2.2\end{array}$ & $\begin{array}{l}2.7 \\
2.3\end{array}$ & $\begin{array}{l}1.4 \\
1.1\end{array}$ & $\begin{array}{l}427 \\
442\end{array}$ & $\begin{array}{l}16467 \\
16954\end{array}$ & \\
\hline $11-23-60$ & 2.0 & 2.1 & 1.0 & 470 & 17723 & \\
\hline $\begin{array}{l}12-5-60 \\
\quad 6\end{array}$ & 1.6 & 2.0 & 0.89 & $\begin{array}{l}482 \\
483\end{array}$ & $\begin{array}{l}18005 \\
18027\end{array}$ & 19055 \\
\hline
\end{tabular}

a From curves in figure 1 and other curves not shown.

b $i_{o}=I p I q /(I p+I q)$.

Weight loss $(\mathrm{g})=K t i$, where $K=2.8938 \times 10^{-4} \mathrm{~g}$ per coulomb, $i=i_{o}=$ Average curred ( $t$ in seconds) between successive readings. The value of $i$ at the instant of exposure and at the end of exposure is taken as the in itial and final values, respectively, as calculated.

d No anodic run; value based on other Ip/Iq ratios around that time.

e No apparent break; value based inversely on relative cathodic and anodic polarization rates $\Delta T / \Delta I$ and $I p$.

During the next 5 months, the corrosion current continued to decrease, presumably due to the drop in air temperature and resultant lowering of soil temperature. The lowest value of corrosion current was observed in March 1960, the coldest time of the vear when the soil resistance was maximum. From this time until the beginning of June, air temperatures continued to rise, soil resistance became lower, and the corrosion current again increased. During the summer 1960, fluctuations in the corrosion current apparently were caused by rainfall. With the coming of colder weather, the soil resistance again increased and the corrosion current diminished. The major fluctuations in potential of the steel occurred
TABLE 2. Weight loss calculated from polarization data on an aluminum specimen exposed underground for 15 months

\begin{tabular}{|c|c|c|c|c|c|c|}
\hline \multirow{2}{*}{$\begin{array}{l}\text { Time of } \\
\text { year }\end{array}$} & \multicolumn{2}{|c|}{$\begin{array}{l}\text { Polarizing current a } \\
\text { at break in curve }\end{array}$} & \multirow{2}{*}{$\begin{array}{c}\text { Corro- } \\
\text { sion b } \\
\text { current } \\
i_{a}\end{array}$} & \multirow{2}{*}{$\underset{\text { Exposure }}{\text { time }}$} & \multicolumn{2}{|c|}{ Weight loss } \\
\hline & $\begin{array}{c}\text { Cathodic } \\
I p\end{array}$ & $\underset{I q}{\text { Anodic }}$ & & & $\begin{array}{l}\text { Calculated c } \\
\text { cumulative }\end{array}$ & Actual \\
\hline $\begin{array}{c}8-12-59 \\
14 \\
19 \\
25\end{array}$ & $\begin{array}{r}m \tau \\
0.15 \\
.17 \\
.12 \\
.10\end{array}$ & $\begin{array}{c}m a \\
0.30 \mathrm{~d} \\
.31 \\
.25 \\
.20\end{array}$ & $\begin{array}{c}m a \\
0.10 \\
.11 \\
.081 \\
.067\end{array}$ & $\begin{array}{c}\text { Days } \\
1 \\
3 \\
8 \\
14\end{array}$ & $\begin{array}{c}m g \\
0.8 \\
2.6 \\
6.4 \\
10.0\end{array}$ & $m g$ \\
\hline $\begin{array}{c}9-4-59 \\
18 \\
29\end{array}$ & $\begin{array}{l}.11 \\
.043 \\
.040\end{array}$ & $\begin{array}{l}.20 \\
.080 \\
.050\end{array}$ & $\begin{array}{l}.071 \\
.028 \\
.022\end{array}$ & $\begin{array}{l}24 \\
38 \\
49\end{array}$ & $\begin{array}{l}15.6 \\
21.1 \\
23.4\end{array}$ & \\
\hline $\begin{array}{c}10-1-59 \\
9 \\
22\end{array}$ & $\begin{array}{l}.039 \\
.035 \\
.032\end{array}$ & $\begin{array}{l}.050 \mathrm{~d} \\
.050 \\
.048\end{array}$ & $\begin{array}{l}.022 \\
.021 \\
.019\end{array}$ & $\begin{array}{l}51 \\
59 \\
72\end{array}$ & $\begin{array}{l}23.8 \\
25.1 \\
27.2\end{array}$ & \\
\hline $\begin{array}{c}11-4-59 \\
13 \\
30\end{array}$ & $\begin{array}{l}.030 \\
.024 \\
.035\end{array}$ & $\begin{array}{l}.050 \\
.043 \\
.068\end{array}$ & $\begin{array}{l}.019 \\
.015 \\
.023\end{array}$ & $\begin{array}{r}85 \\
94 \\
111\end{array}$ & $\begin{array}{l}29.3 \\
30.5 \\
33.1\end{array}$ & \\
\hline $12-22-59$ & .034 & .062 & .022 & 133 & 37.2 & \\
\hline $\begin{array}{l}1-13-60 \\
26\end{array}$ & $\begin{array}{l}.023 \\
.012\end{array}$ & $\begin{array}{l}.055 \\
.043\end{array}$ & $\begin{array}{l}.016 \\
.009\end{array}$ & $\begin{array}{l}155 \\
168\end{array}$ & $\begin{array}{l}40.6 \\
41.9\end{array}$ & \\
\hline 2-19-60 & .016 & .042 & .012 & 192 & 43.8 & \\
\hline $\begin{array}{c}3-4-60 \\
9 \\
25\end{array}$ & $\begin{array}{l}.012 \\
.011 \\
.014\end{array}$ & $\begin{array}{l}.037 \\
.035 \\
.033\end{array}$ & $\begin{array}{l}.009 \\
.008 \\
.010\end{array}$ & $\begin{array}{l}206 \\
211 \\
227\end{array}$ & $\begin{array}{l}45.0 \\
45.3 \\
46.5\end{array}$ & \\
\hline $\begin{array}{l}4-6-60 \\
28\end{array}$ & $\begin{array}{l}.016 \\
.016\end{array}$ & $\begin{array}{l}.056 \\
.040\end{array}$ & $\begin{array}{l}.012 \\
.011\end{array}$ & $\begin{array}{l}239 \\
261\end{array}$ & $\begin{array}{l}47.6 \\
49.7\end{array}$ & \\
\hline $\begin{array}{l}5-20-60 \\
23\end{array}$ & $\begin{array}{l}.014 \\
.011\end{array}$ & $.042^{\mathrm{d}}$ & $\begin{array}{l}.011 \\
.009\end{array}$ & $\begin{array}{l}283 \\
286\end{array}$ & $\begin{array}{l}51.7 \\
51.9\end{array}$ & \\
\hline $\begin{array}{l}6-15-60 \\
30\end{array}$ & $\begin{array}{l}.012 \\
.009\end{array}$ & $\begin{array}{l}.022 \\
.020\end{array}$ & $\begin{array}{l}.008 \\
.006\end{array}$ & $\begin{array}{l}309 \\
324\end{array}$ & $\begin{array}{l}53.6 \\
54.4\end{array}$ & \\
\hline $\begin{array}{l}7-18-60 \\
26\end{array}$ & $\begin{array}{l}.008 \\
.008\end{array}$ & $\begin{array}{l}.015 \\
.015\end{array}$ & $\begin{array}{l}.005 \\
.005\end{array}$ & $\begin{array}{l}342 \\
350\end{array}$ & $\begin{array}{l}55.1 \\
55.4\end{array}$ & \\
\hline $\begin{array}{c}8-1-60 \\
19\end{array}$ & $\begin{array}{l}.009 \\
.011\end{array}$ & $\begin{array}{l}.012 \\
.013\end{array}$ & $\begin{array}{l}.005 \\
.006\end{array}$ & $\begin{array}{l}356 \\
374\end{array}$ & $\begin{array}{l}55.6 \\
56.5\end{array}$ & \\
\hline $9-1-60$ & .008 & $\begin{array}{l}.011 \\
.012\end{array}$ & $\begin{array}{l}.005 \\
.006\end{array}$ & $\begin{array}{l}387 \\
400\end{array}$ & $\begin{array}{l}57.0 \\
57.6\end{array}$ & \\
\hline$\stackrel{10-11-60}{26}$ & $\begin{array}{l}.007 \\
.006\end{array}$ & .011 & $\begin{array}{l}.004 \\
.003\end{array}$ & $\begin{array}{l}427 \\
442\end{array}$ & $\begin{array}{l}58.7 \\
59.1\end{array}$ & \\
\hline $11-23-60$ & .007 & .007 & .004 & 470 & 60.0 & \\
\hline $\begin{array}{l}12-5-60 \\
6\end{array}$ & .006 & .006 & .003 & $\begin{array}{l}482 \\
483\end{array}$ & $\begin{array}{l}60.4 \\
60.7\end{array}$ & 109 \\
\hline
\end{tabular}

a From curves in figure 2 and other curves not shown.

ь $i_{o}=I p I q /(I p+I q)$.

Same as footnote in table 1, except $K=0.9316 \times 10^{-4} \mathrm{~g}$ per coulomb.

d No anodic run; value based on other Ip/Iq ratios around that time.

during the early months of exposure. After the corrosion products began to build up, there was a tendency for the potential to become gradually more electropositive.

The corrosion rate of the aluminum seemed to be less affected by changes in weather than that of the steel. The current for the aluminum (fig. 4) dropped considerably during the first 2 months and gradually thereafter. In contrast with the steel, the aluminum corrosion current decreased about 30 -fold while that of the steel decreased around 8-fold during the 16 months.

After the specimens had been cleaned, the pit depths were also measured. On the steel, the maximum pit depth was $0.035 \mathrm{in}$. and the six deepest pits averaged 0.03 in. For the aluminum, the maximum pit depth was 0.008 in. The six deepest pits averaged 0.007 in. 


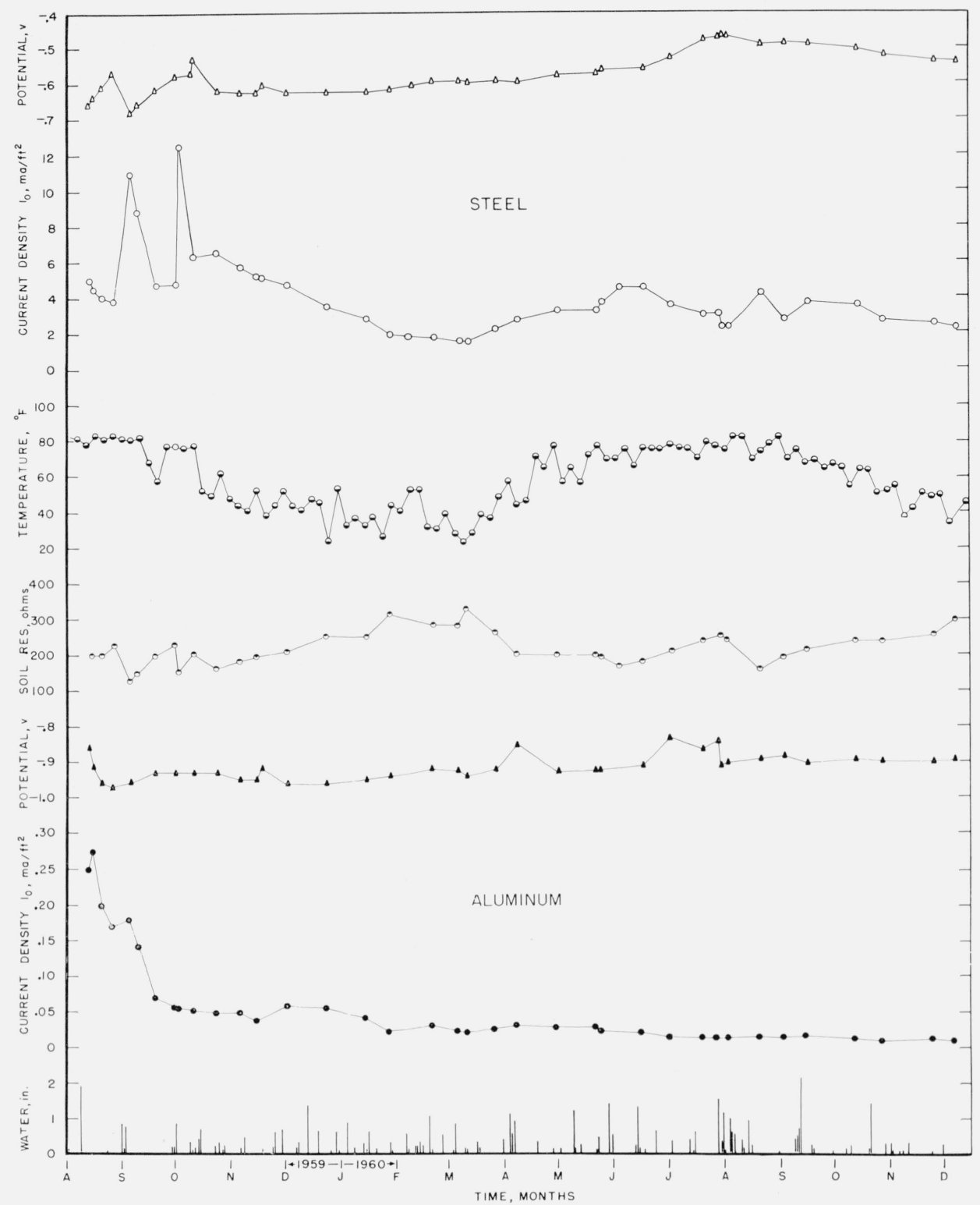

FIGURE 4. Effect of time and weather on the corrosion rate and potential of steel and aluminum exposed underground for 16 months.

\begin{abstract}
$\triangle$ Potential, steel; $\bigcirc$ corrosion current, steel; 9 air temperature; $\mathbf{A}$ potential, aluminum; corrosion current, alumi-
num; soil resistance, between steel specimen and reference electrode; $\mid$ precipitation (water) in area-U.S. Weather Bureau.
\end{abstract}

\section{Summary}

A steel and an aluminum specimen were exposed underground for 16 months to a soil having an average resistivity of about $7500 \mathrm{ohm}-\mathrm{cm}$. During this time, cathodic and anodic polarization curves were automatically recorded on 40 occasions with the idea of evaluating a technique for measuring rates of corrosion and noting the effects of the weather on such rates.

The weight loss of each material caused by corrosion agreed quite well with the calculated losses based on the polarization data. The cathodic polarization data for both the steel and aluminum seem to fit reasonably well a logarithmic relationship, discussed in a previous publication [2], which is helpful in anticipating rates of corrosion.

Both materials corroded at a faster rate during the early months of exposure than later. The corrosion rate of the aluminum diminished more rapidly and to a greater degree than that of the steel. The corrosion rate of the steel was affected more by temperature and rainfall than was that of the aluminum.

This investigation was not intended to evaluate the relative merits of the metals exposed to corrosion. While their relative behavior is of interest, it must be remembered that only one soil environment was involved. 
The weather data were copied from the local climatological data sheets, U.S. Department of Commerce, Weather Bureau.

\section{References}

[1] W. J. Schwerdtfeger, Measurement of the corrosion rate of a metal from its polarizing characteristics, J. Electrochem. Soc. 99, 407 (1952).

[2] W. J. Schwerdtfeger and Raul J. Manuele, Coatings formed on steel by cathodic protection and their evaluation by polarization measurements, J. Research NBS 65C, (July-Sept. 1961).
[3] R. V. Skold and T. E. Larson, Measurement of the instantaneous corrosion rate by means of polarization data, Corrosion 13, $139 t$ (Feb. 1957).

[4] W. J. Schwerdtfeger, Current and potential relations for the cathodic protection of steel in a high-resistivity environment, J. Research NBS 63C, 37 (July-Sept. 1959), Corrosion 16 (May 1960).

(Paper 65C4-80) 